\title{
Research on C2C E-Commerce Taxation Based on Mixed Decision Game
}

\author{
Jiamian Yu, XiHua University, Chengdu, China \\ Haiyan Yu, XiHua University, Chengdu, China
}

\begin{abstract}
The rapid rise of $\mathrm{C} 2 \mathrm{C}$ e-commerce in China has brought serious difficulties to China's tax collection and management. Based on the principle of progressive taxation, the necessity of taxation on $\mathrm{C} 2 \mathrm{C}$ e-commerce is analyzed and discussed. It is shown that the absence of taxation in C2C e-commerce is contrary to the principle of tax equity and tax neutrality, and the tax revenue is lost. It is demonstrated that it is imperative that China to implement $\mathrm{C} 2 \mathrm{C}$ e-commerce taxation in a comprehensive and standardized way. By constructing a hybrid decision game model between $\mathrm{C} 2 \mathrm{C}$ business operators and tax authorities, the static game analysis of incomplete information is conducted for the balance of interests between tax authorities and e-commerce operators.
\end{abstract}

\section{KEYWORDS}

C2C E-Commerce, Modern Taxation, Tax Equity, Tax Neutrality

\section{INTRODUCTION}

In recent years, e-commerce has developed rapidly in China, and its business scale and transaction volume have increased significantly, and a mature business model has been formed. According to AI statistics, in 2016, the scale of China's e-commerce market exceeded 20 trillion yuan for the first time, ranking first in the world, and will maintain steady and rapid growth in the next few years (Biswas, 2018). E-commerce has gradually changed people's trading concepts and greatly affected our consumption patterns.

The impact of e-commerce on traditional taxation and the loss of tax revenue is also increasing. Therefore, whether to cope with e-commerce taxation and how to levy taxes has become the focus of attention in the social and academic circles.

The mainstream e-commerce is mainly divided into three categories: B2B (enterprise to enterprise), B2C (enterprise to consumer) and $\mathrm{C} 2 \mathrm{C}$ (consumer to consumer). B2B and B2C rely on entity registration companies online, that is, a positive tax entity. The two types of e-commerce, B2C and $\mathrm{B} 2 \mathrm{~B}$, can be taxed in accordance with the traditional offline entity transaction methods, while China's B2C and B2B have combined traditional invoices and electronic invoices to pay taxes. B2C suppliers such as JD.com, Yihaodian and Tmall are paying taxes. Therefore, the tax collection and management of the above two categories of e-commerce are indisputable. Compared with the above two models, $\mathrm{C} 2 \mathrm{C}$ tax entities are difficult to materialize, and the transaction location is online. $\mathrm{C} 2 \mathrm{C}$ accounts for a relatively large proportion of China's e-commerce transactions, having exceeded 50\% before 2014 and accounted for $48.1 \%$ in 2015. The tax gap of C2C e-commerce has brought a lot of tax losses to our country, which has seriously affected the principles of tax equity and tax neutrality. 
In this context, it is particularly necessary to study the taxation issues of $\mathrm{C} 2 \mathrm{C}$ e-commerce. The research will help strengthen the market supervision of e-commerce and promote the improvement of the tax system. It is feasible and effective to analyze the necessity and main line of tax collection and management of $\mathrm{C} 2 \mathrm{C}$ e-commerce through tax principle theory and game analysis. The suggestions made based on the analysis results also have good reference significance.

The innovation of this research is reflected in three aspects: research perspective, research content and research design. From the perspective of research, the article chooses $\mathrm{C} 2 \mathrm{C}$ business operators as the starting point and the tax authorities as participants in game analysis. This research method broadens the existing research ideas in the field of e-commerce, and opens up new ideas for the optimization of e-commerce taxation practices. The tax issue of $\mathrm{C} 2 \mathrm{C}$ e-commerce selected in this paper is not only the bottleneck of the development of the e-commerce industry, but also the focus of e-commerce research, and further enriches the research results of $\mathrm{C} 2 \mathrm{C} \mathrm{e}$-commerce taxation. From the two aspects of the necessity of $\mathrm{C} 2 \mathrm{C}$ e-commerce taxation and the $\mathrm{C} 2 \mathrm{C}$ game analysis of the hybrid decision of e-commerce taxation, the qualitative and quantitative analysis is carried out respectively. Full consideration of the interest relationship of $\mathrm{C} 2 \mathrm{C}$-commerce sales entities is an effective practice of monetary theory and taxation theory, and the result is more reliable, rigorous and scientific.(llie s,2006;Judge,2002;Judge,1998;Judge,2013;23.Fabisiak,2018;Shahri,2019;Peng,2019; Pham,2019)

\section{LITERATURE REVIEW}

Electronic commerce (electronic commerce) refers to the use of electronic communication equipment and technology to conduct various commodities, technology and service transactions between parties or multiple parties. Generally speaking, e-commerce also includes commercial transactions conducted by transaction parties through fax communication, but in a strict sense, e-commerce refers to electronic data interchange (EDI) and Internet (Internet) based on the wide application of computer technology. Commercial transactions. Compared with traditional international trade, the liquidity and flexibility of e-commerce has been strengthened, but in fact it has brought new challenges in the field of international taxation. As mentioned above, in the traditional business environment, international taxation has jurisdiction. Although there are some international tax evasion problems, long-term practical research has also produced some solutions. However, the advent of the e-commerce era has brought some new challenges.(Al-Momani,2018; Grubljesic,2019;14.zhang,2019;Gentile,2012 ;llies,2009)

Due to the wide coverage of e-commerce, the specific objects involved in different e-commerce application systems also have their particularities. In general, an e-commerce system usually includes the basic components shown in Figure 1. As can be seen from Figure 1, the electronic Business activities are based on the network system and involve the participation and support of multiple parties in society, such as network systems, users, banks, distribution centers, certification bodies, and administrative departments.

The e-commerce system structure refers to the collection of the external environment and internal components of the system. E-commerce system is not an isolated system, including network, computer system, application software, etc. At the same time, it also needs to communicate with the outside world. Therefore, introducing the structure of the e-commerce system helps us understand the internal structure of e-commerce, the external operating environment and the relationship between them, and understand e-commerce from a macro level.

Many people think that the construction of an e-commerce system is to create a website. This understanding is incomplete. E-commerce includes various applications such as online stock trading, online job hunting, online shopping, online marketing, online auctions, etc. The construction of an e-commerce system is a system engineering that can support multiple applications and requires a broad society stand by. The project includes not only the construction of network infrastructure, but also the construction of closely related content services, payment services, security services, 


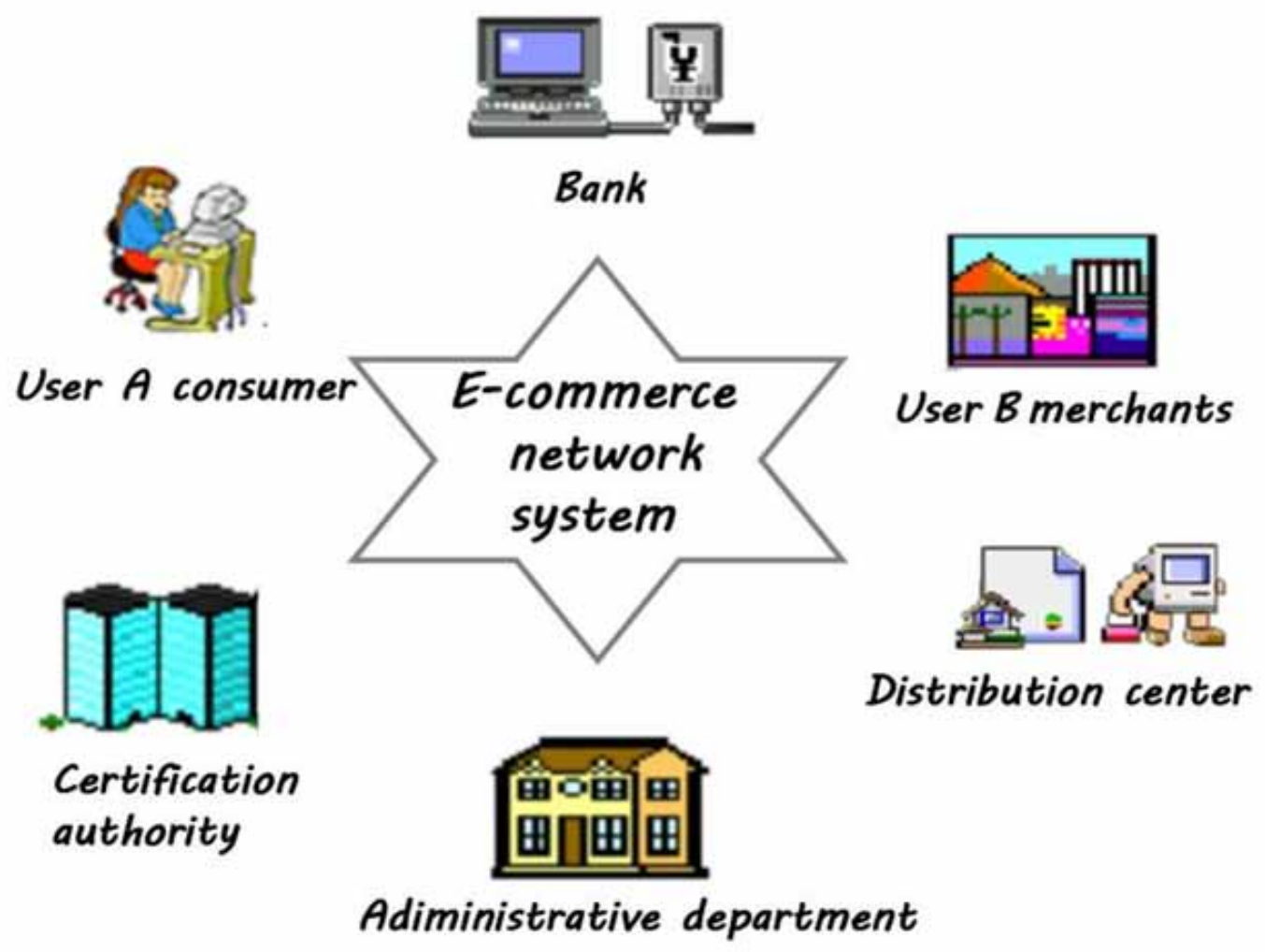

logistics services, etc. The basic service platform also depends on the continuous improvement of soft environments such as public policies and technical standards. The e-commerce system structure can be observed in Figure 2.

Judging from the current research results, the analysis of tax entities by foreign scholars is mainly concentrated in the field of e-commerce. There are also many studies on the impact and relationship of tax entity behavior in a specified field. For example, Cobiac LJ etc. (Ramakrishnan,2010) analyzes the taxation of tobacco industry and puts forward some suggestions and countermeasures to the taxation behavior of the industry. There are limited studies on the subject of tax revenue in China. The research contents of academic achievements mainly include the following aspects: Firstly, tax liability analysis and tax role analysis based on economic theory and legal regulations; Secondly, the relationship and influence between tax planning and tax subjects. Ding Weirong fully considers the interests of e-commerce tax subjects, and builds a tax collection and management model suitable for China's e-commerce based on the review of the Korean e-commerce tax collection and management system and model(Lu,2010). Wang, HL discussed how to determine the jurisdiction and jurisdiction of e-commerce tax entities (Jiang,2005). Most of the research on the behavior of taxation subjects is qualitative analysis based on economic theories and legal rules. There are relatively few related literatures on e-commerce tax collection and management with e-commerce taxation as the main body.

In recent years, e-commerce taxation has gradually become a hot topic in the field of e-commerce research in China. The research contents include the following aspects: At first, whether e-commerce tax should be imposed on the basis of China's national conditions. Wang Jing discussed the current controversial issues of e-commerce taxation, and fully considered my country's national conditions, 


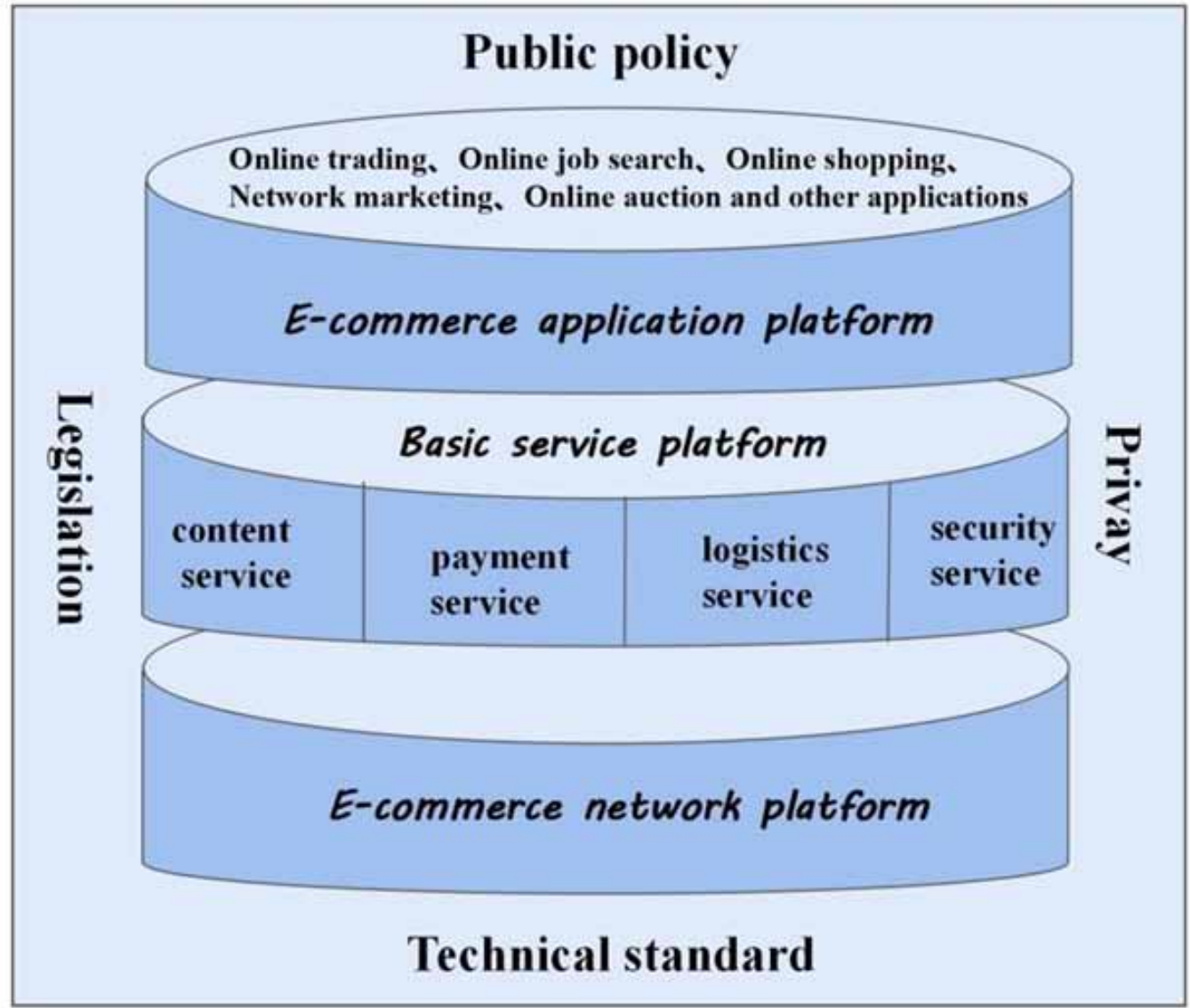

the development status of e-commerce and social needs. It is recommended to levy taxes on Chinese e-commerce entities, determine reasonable tax jurisdiction, and appropriately raise the threshold of online retailers(Zhang,2007). The second is to analyze the obstacles and challenges faced by my country's e-commerce taxation from the actual situation and theory. Wang Tingting and Hou Huan point out that the characteristics of "fictitious, hidden and paperless" of e-commerce have brought difficulties to taxation. It also brings problems such as weakening of traditional tax vouchers, increasing management difficulty, and increasing tax costs. But at the same time, big data also provides opportunities for database tracking and facilitation. Bai Yanfeng used data from China's online shopping markets as a sample since 2006, conducted an empirical analysis on the tax fairness of e-commerce and physical retail, and put forward suggestions for optimizing traditional tax collection and management processes and methods. E-commerce taxation promotes fair competition between the two and reduces regional financial tax losses (Lee, 2001). In recent years, scholars in China have started to pay attention to the study of tax issues in $\mathrm{C} 2 \mathrm{C}$ e-commerce. From the perspective of establishing a fair market environment and based on the $\mathrm{C} 2 \mathrm{C}$ business model, Wang Fengfei puts forward suggestions on strengthening tax supervision, establishing standards for tax elements, and building an online tax management platform. In order to promote tax fairness, Zhang Jing believes that the implementation of $\mathrm{C} 2 \mathrm{C}$ e-commerce tax collection and management is an inevitable trend of progress and puts forward suggestions for C2C e-commerce tax regulation management (Zhao, 2003). 
It can be seen that the taxation difficulties of e-commerce have brought many adverse effects on the development of the Chinese government and the market. At present, domestic and foreign research on e-commerce taxation mainly focuses on e-commerce taxation models, e-commerce tax equalization, and e-commerce tax loss. The discussion and analysis of specific categories of e-commerce (B2B, B2C and C2C) is still in infancy, and various types of e-commerce have large differences in operation methods and market development. The article thinks that we should do research and analysis from a different angle, aiming at analyzing a certain type of e-commerce taxation. In addition, the research methods of scholars are mostly theoretical research, with less quantitative analysis and weak persuasiveness. It can be seen that the research on the subject of e-commerce taxation is not deep enough.

Based on the summary of the above literature, this article will establish a game model to analyze the subject of $\mathrm{C} 2 \mathrm{C}$ e-commerce taxation with a quantitative method, find the balance between the tax entity and the subject of e-commerce business, and propose solutions by balancing the influence of various variables.

\section{THE NECESSITY OF TAX COLLECTION AND MANAGEMENT OF C2C E-COMMERCE}

At present, the question of whether or not to deal with $\mathrm{C} 2 \mathrm{C}$ business tax has caused widespread controversy in the society and academia. Based on the impact of $\mathrm{C} 2 \mathrm{C}$ taxation gap on my country's fiscal revenue, the article discusses and analyzes the necessity and importance of my country's implementation and strengthening of $\mathrm{C} 2 \mathrm{C}$ e-commerce tax collection and management combined with modern taxation theory.

\section{Avoid Tax Evasion}

The purpose of taxation is to ensure the financial revenue of the state, meet the state's executive functions and social public needs. However, in $\mathrm{C} 2 \mathrm{C}$ e-commerce, transactions are completed on paperless networks. Currently, the tax authorities have not issued extensive control measures, nor have they issued e-commerce-related tax laws, nor have they imposed large-scale taxation on $\mathrm{C} 2 \mathrm{C}$ business entities. The tax management of $\mathrm{C} 2 \mathrm{C}$ e-commerce is still in a tax opaque area in my country. In 2016, the online retail market has reached 2 trillion and 300 billion yuan, and my country has not yet imposed taxes on $\mathrm{C} 2 \mathrm{C}$ e-commerce. This "tax blind zone" is bound to bring huge losses to my country's taxation (Fan,2004). In order to protect our national interests, the issue of tax collection and management of $\mathrm{C} 2 \mathrm{C}$ e-commerce is imminent and urgent to be solved.

\section{Maintaining the Principle of Fairness in Taxation}

In China, there is no clear regulation on the relevant $\mathrm{C} 2 \mathrm{C}$ e-commerce transaction tax law. However, the development of $\mathrm{C} 2 \mathrm{C} \mathrm{e}$-commerce in China is quite large, and the trading mode is relatively mature at present. The nature of e-commerce transactions is basically the same as physical transactions, and there is no essential difference. E-commerce transactions can be considered as a trading behavior only in comparison with customary trade methods. According to China's applicable tax laws, C2C has been recognized as a transaction activity, which meets tax requirements. Take Taobao (the largest $\mathrm{C} 2 \mathrm{C}$ e-commerce website in China) as an example. The owners of Taobao stores are all registered individuals with real names, and there are also a large number of products sold online. Every transaction involves currency and commodity transactions with buyers. The behavior accords with our tax standard and should be placed on the tax authorities according to a certain proportion.

C2C e-business tax gap will impact on other trading modes, unfair to offline stores, transaction costs and sales prices are less than offline stores, affecting market competition norms, resulting in more and more consumers tend to Taobao shopping, which will seriously affect physical store operations in China. The tax exemption for $\mathrm{C} 2 \mathrm{C}$ e-commerce business units and the taxation of entity enterprises 
violated the original intention of paying taxes to correct the uneven distribution of income, leading to the widening of the income gap. When taxpayers believe that the tax system is reasonable and the tax burden is reasonable, they can be encouraged to declare honestly and pay taxes in accordance with the law. Only in this way can the normal operation of the tax system be maintained. Therefore, the taxation gap of $\mathrm{C} 2 \mathrm{C}$ e-commerce will affect the stable development of my country's market economy and have a negative impact on the operation of my country's traditional taxation system.

\section{Maintain the Principle of Tax Neutrality}

Tax neutrality is a tax policy for different products or services, separate factors of production income and different types of producers. A fair and unconstrained tax policy does not inhibit tax revenue, but only affects the total amount of taxation, and does not affect the product production structure and capital investment. The principle of tax neutrality requires that different ways of buying or dealing with different kinds of technology should receive by the same tax treatment (Li,2011;Tan,2004;Iva naj,2019; Wei,2019).

C2C tax loopholes have clearly distorted the capital structure of the Chinese market. Due to the low cost and low risk of $\mathrm{C} 2 \mathrm{C} \mathrm{e}$-commerce, more and more companies have abandoned the traditional business model and decided to enter the e-commerce market. Meanwhile, more and more investment funds are transferred from the offline transaction market to the e-commerce market. The parties take advantage of regulatory loopholes of the tax authorities to conduct $\mathrm{B} 2 \mathrm{C}$ mode transactions in the name of $\mathrm{C} 2 \mathrm{C}$ mode to achieve the purpose of tax evasion. Obviously, operators have been affected by the $\mathrm{C} 2 \mathrm{C}$ tax gap to a certain extent and violated their business methods.

\section{GAME ANALYSIS OF C2C E-COMMERCE TAXATION SUBJECT BEHAVIOR}

C2C e-commerce is quite different from traditional business, which is mainly reflected in the operation Random locations, inability to monitor transactions and payments, small but large number of merchants, etc. These characteristics make it difficult to fully implement the monitoring of $\mathrm{C} 2 \mathrm{C}$ e-commerce behavior, which poses a serious obstacle to taxation. Therefore, the $\mathrm{C} 2 \mathrm{C}$ e-commerce taxpayer's main body's decision-making on the impact of taxation feasibility is crucial. By constructing a game model analysis, the optimal decision of both parties can be obtained, and the development of $\mathrm{C} 2 \mathrm{C}$ e-commerce taxation can be promoted. The research has practical significance.

\section{Model Assumptions}

Hypothesis 1: As the main sales entity of $\mathrm{C} 2 \mathrm{C}$ e-commerce and the tax authorities participating in the same model, both parties are rational economic persons. The goal of both parties is to maximize profits.

Hypothesis 2: The sales entity does not know whether the tax authority will inspect it, nor does the tax authority know the seller's actual sales and actual conditions, that is, the two parties have incomplete information on mutual characteristics, strategic space and payment functions.

Hypothesis 3: The $\mathrm{C} 2 \mathrm{C}$ business is taxable or non-taxable. Tax payment refers to whether a company actually pays taxes when taxing $\mathrm{C} 2 \mathrm{C}$ e-commerce by tax authorities. Non-tax payment means that the tax authorities choose to evade tax without paying $\mathrm{C} 2 \mathrm{C}$ e-commerce tax. The strategic space for tax authorities is to inspect or not inspect. Non-inspection refers to taxation of the primary operator.

Hypothesis 4: To simplify the research, this article only considers the collection of income tax and it is built on the proportional tax collection income tax. 
Table 1. Gain matrix of both sides of the game.

\begin{tabular}{|c|l|l|}
\hline E-Commerce Business Entity & \multicolumn{1}{|c|}{ Check } & \multicolumn{1}{c|}{ Not Check } \\
\hline Pay taxes & $e-e t, e t-c$ & $e-e t, e t$ \\
\hline Not pay tax & $e-f-e t, f+e t-c$ & $e, 0$ \\
\hline
\end{tabular}

\section{Model Building}

According to the model assumptions, the game is a static game with incomplete information. Assuming that the taxable income of the business operator is $e$, the income tax rate in the $\mathrm{C} 2 \mathrm{C}$ e-commerce market is $t$, and the tax authorities' inspection costs are $c(c<e t)$; When a business operator commits tax evasion, once verified by the tax authority, the probability of paying tax is $f$. Business operators are $p_{1} \in[0,1]$, and probability of nonexistence $p_{2} \in[0,1]$. The probability of choosing non-audit is $1-p_{2}$. . There are four kinds of game strategies:

Firstly, the main business operators choose to pay taxes, and the tax authorities choose to check. The profit of business operators is $e-e t$, and the revenue from the tax authorities is $e t-c$.

Secondly, the main business operators choose to pay taxes, and the tax authorities choose not to check. The profit of the main business is $e-e t$, and the revenue of the tax authorities is $e t$.

Thirdly, the main business operators choose not to pay taxes, the tax authorities choose to check, then the income of the main body of the e-commerce business is $e-f-e t$, and the income of the tax authority is $f+e t-c$;

Fourthly, if the e-commerce business entity chooses not to pay taxes and the tax authority chooses not to audit, then the e-commerce business entity's revenue is $e$, and the tax authority's revenue is 0 .

According to the problem assumption and strategy space above, the gain matrix of this game is specific as shown in Table 1.

According to the above analysis, the expected income function of the e-commerce business entity can be obtained:

$$
\pi_{1}=p_{1}\left[p_{2} \bullet e(1-t)+\left(1-p_{2}\right) \bullet e(1-t)\right]+\left(1-p_{1}\right)\left[p_{2}(e-f-e t)+\left(1-p_{2}\right) e\right]
$$

In this game, each e-commerce business entity is a rational economic person, so they will choose the appropriate $p_{1}$ to maximize their profits. In summary, the first-order conditions for the optimization of the main business strategy of the e-commerce business can be expressed as:

$$
\frac{\partial \pi_{1}}{\partial p_{1}}=e-p_{2}(e t+f)=0
$$

$$
\text { Solved } p_{2}^{*}=\frac{e t}{e t+f}
$$

It can be seen from the above that when the probability of the tax agency selecting the audit is greater than $p_{2}^{*}$, the optimal strategy of the e-commerce business entity is to pay taxes; If the probability that the tax agency chooses to audit is less than $p_{2}^{*}$, the optimal strategy for the e-commerce business entity is not to pay taxes; When the probability of being inspected by the tax authority is equal to $p_{2}^{*}$, 
Table 2. The best reflection function of the main body of e-commerce business.

\begin{tabular}{|l|l|}
\hline Value of $p_{1}$ & condition \\
\hline 0 & If $p_{2}<\frac{e t}{e t+f}$ \\
\hline$(0,1)$ & If $p_{2}=\frac{e t}{e t+f}$ \\
\hline 1 & If $p_{2}>\frac{e t}{e t+f}$ \\
\hline
\end{tabular}

the e-commerce business entity will randomly choose to pay tax or not to pay tax. According to the above analysis, the best reflection function of the e-commerce business entity can be obtained, as shown in Table 2.

Similarly, the expected income function of the tax authority can be expressed as:

$$
\pi_{2}=p_{2}\left[p_{1}(e t-c)+\left(1-p_{1}\right)(f+e t-c)\right]+\left(1-p_{2}\right)\left[p_{1} \bullet e t+\left(1-p_{2}\right) \bullet 0\right]
$$

For tax authorities, the optimal first-order conditions are:

$$
\begin{aligned}
& \frac{\partial \pi_{2}}{\partial p_{2}}=-p_{1} \bullet c+c-e t-f=0 \\
& p_{1}^{*}=1-\frac{e t+f}{c}
\end{aligned}
$$

Therefore, when the probability of tax payment by the e-commerce business entity is less than $p_{1}^{*}$, the tax agency 's optimal strategy is auditing; When the probability of tax payment by the e-commerce business entity is greater than $p_{1}^{*}$, the tax agency 's optimal strategy is not to audit; The probability of a business entity paying taxes is equal to $p_{1}^{*}$, and the tax authority randomly chooses whether to audit. Through the above analysis, the best response function of the tax authority can be obtained, as shown in Table 3.

Based on the above analysis, the reaction curves of both players (e-commerce operators and tax authorities) are shown in Figure 3. The Nash equilibrium point is the intersection of two functional curves.

Therefore, $p_{1}^{*}=1-\frac{e t+f}{c}$ and $p_{2}^{*}=\frac{e t}{e t+f}$ are the Nash equilibrium points of the mixed strategy game between e-commerce business entities and tax authorities in $\mathrm{C} 2 \mathrm{C}$ e-commerce. 
Table 3. The best reflection function of the tax authorities

\begin{tabular}{|l|l|}
\hline Value of $p_{2}$ & Condition \\
\hline 0 & If $p_{1}<1-\frac{e t+f}{c}$ \\
\hline$(0,1)$ & If $p_{1}=1-\frac{e t+f}{c}$ \\
\hline 1 & If $p_{1}>1-\frac{e t+f}{c}$ \\
\hline
\end{tabular}

\section{Results Analysis}

In order to maximize the benefits, e-commerce entities, as the main interest entities, have launched a game with taxation authorities with tax inspection as a strategic space. According to $p_{1}^{*}=1-\frac{e t+f}{c}$, under the premise that the taxable income remains unchanged, if the e-commerce income tax rate is reduced, the probability of e-commerce operators taking the initiative to pay taxes will increase; It can be concluded from $p_{2}^{*}=\frac{e t}{e t+f}$ that the amount of tax evasion of a business entity is inversely proportional to the inspection probability of the tax authority, that is, the greater the amount of tax evasion, the greater the audit probability of the tax authority, which is consistent with the actual situation. In addition, increasing the tax evasion penalty will reduce the probability of inspection by the tax authority, thereby reducing the total audit cost of the tax authority. Firstly, the probability of $\mathrm{C} 2 \mathrm{C}$ e-commerce business entities paying taxes depends on the income tax rate and the penalty for tax evasion. At the beginning of the game, the main body of e-commerce business complies with market rules and does not have the subjective possibility of tax evasion. The goal pursued by e-commerce entities that satisfy the assumption of "economic man" is to maximize profits. As profits increase, taxes gradually increase and high taxes will affect their taxation decisions. At the same time, because $\mathrm{C} 2 \mathrm{C}$ electronic commerce transactions have a certain concealment, it will encourage the evasion of taxation and punishment by enterprises of e-commerce business entities. The income tax rate is a direct factor in determining taxation, and it will inevitably affect the taxation decisions of e-commerce operators. In addition, tax evasion fines are a powerful means to punish tax evasion, and e-commerce entities will inevitably take this illegal cost as one of the important reference factors for taxation decisions. Secondly, the inspection probability of the tax authority depends on the amount of tax evasion and tax evasion penalties of $\mathrm{C} 2 \mathrm{C}$ e-commerce business entities. Small-value transactions in $\mathrm{C} 2 \mathrm{C}$ e-commerce are often difficult to monitor, and tax evasion at this time can easily evade inspection by tax authorities. With the continuous increase in transaction volume, the number of tax evasion and tax evasion will also increase, industry influence will gradually appear, and the possibility of being audited has greatly increased. When the amount of tax evasion fines is large, the business entity must consider the cost of illegality, reduce the probability of tax evasion, and also reduce the probability of tax audits. 
Figure 3. The mixed strategy Nash equilibrium of $\mathrm{C} 2 \mathrm{C}$ e-commerce business entities and tax authorities.

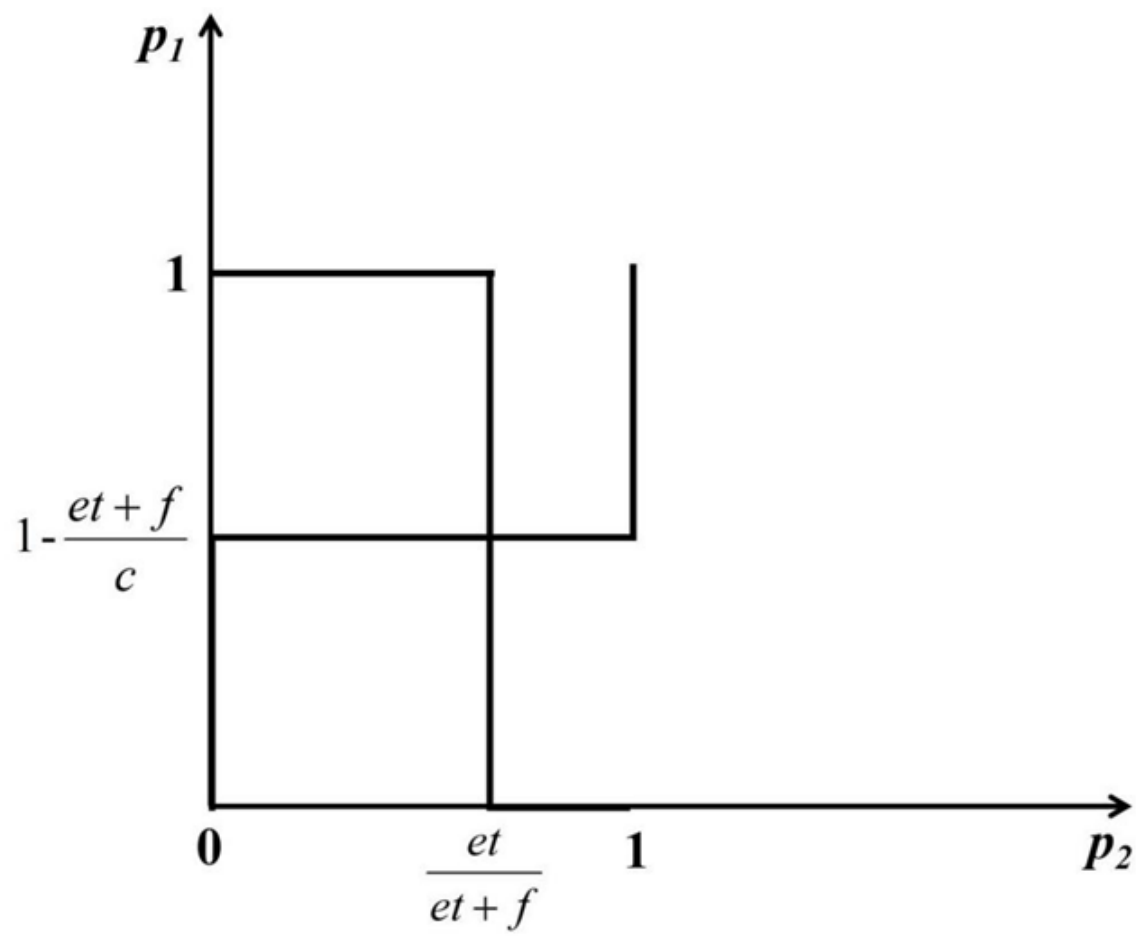

\section{COUNTERMEASURES AND SUGGESTIONS FOR C2C E-COMMERCE TAXATION}

From the above analysis, it can be seen that as long as the tax authority adopts an appropriate tax rate and punishment mechanism, it can promote the orderly payment of $\mathrm{C} 2 \mathrm{C}$ e-commerce business entities and increase the initiative of e-commerce tax payment. Not only can it effectively improve tax losses, but can also promote the balanced development of my country's overall trading market. It can be achieved in the following ways.

\section{Implementation of C2C E-Commerce Preferential Tax Policies}

At present, China's $\mathrm{C} 2 \mathrm{C}$ e-commerce market is relatively large, with a large number of outlets and high liquidity. It creates resistance to merchants, which in turn causes a large amount of tax evasion. According to the results of the game model, appropriately reducing the tax rate will increase the initiative of the enterprise. Based on the particularity of $\mathrm{C} 2 \mathrm{C}$ e-commerce, it can be distinguished from traditional tax policies by reducing the tax rate of e-commerce operators and encouraging the development of e-commerce. In addition, the tax authority can also give $\mathrm{C} 2 \mathrm{C}$ e-commerce business entities some encouragement and care, such as reducing or exempting part of the taxable amount and reimbursing a certain percentage of the taxable amount, etc. Certain tax incentives granted to the $\mathrm{C} 2 \mathrm{C}$ e-commerce market are also based on the principle of tax flexibility. Only under this flexible tax system can my country achieve tax leverage and achieve appropriate economic intervention and economic regulation.

\section{Increasing Tax Evasion Fines and Severely Punishing Tax Evasion Behaviors}

According to the above analysis results, it can be observed that increasing tax evasion fines will also promote the probability of tax payments by e-commerce business entities. From a practical point of 
view, the higher the tax evasion penalty, the greater the restriction on the tax evasion of online stores. Severely cracking down on tax evasion will play a deterrent effect on the $\mathrm{C} 2 \mathrm{C}$ e-commerce market, thereby purifying the e-commerce tax environment. A high penalty for tax evasion will also make up for the loss of e-commerce taxation in China to a certain extent, reducing the incidence of audits by tax authorities and saving manpower and material resources. In addition, different punishment amounts can be set according to the amount of tax evasion, and higher penalties are charged e-commerce companies with larger tax evasion amounts, so that the punishment system has the same deterrent effect on e-commerce entities with diverse incomes.

\section{Taxation by Monitoring the Third-Party Payment Platform}

At present, China's C2C market has a large number of shops, wide distribution, high anonymity, and it is difficult to levy taxes. If taxes are levied in the traditional way, it will consume a lot of manpower, material and financial resources, greatly increase tax costs, and violate the principle of tax efficiency. China's C2C trading platform is relatively single, and Taobao has occupied most of the market share. Each trading platform has a third-party payment platform, and the tax authority can monitor the transaction behavior of the transaction subject through the third-party platform. For example, transactions on Taobao, the largest $\mathrm{C} 2 \mathrm{C}$ e-commerce platform, are provided by Alipay. Therefore, Alipay can easily determine the transaction amount and the number of transactions for each seller. The tax authority can negotiate with the third-party platform and deduct each transaction according to the established tax rate, and collect the subject's tax through Alipay to facilitate cooperation with the third-party payment platform. Tax authorities can give third-party payment platforms a certain percentage of commissions to increase their enthusiasm for participation. While ensuring the principle of tax efficiency, it promotes the smooth implementation of taxation.

\section{CONCLUSION}

With the rapid development of e-commerce in China, the taxation gap of $\mathrm{C} 2 \mathrm{C}$ e-commerce has seriously affected the tax revenue in China, resulting in the loss of tax revenue, and impairs the principles of tax fairness and tax neutrality. It has caused unfair behavior to the operation of traditional offline stores in China and distorted the balance of market structure. Therefore, it is necessary to tax $\mathrm{C} 2 \mathrm{C}$ e-commerce. The problem of taxation gap is an urgent problem in our country. However, the large number of online shops and wide distribution of $\mathrm{C} 2 \mathrm{C} \mathrm{e}$-commerce have brought great difficulties to our tax authorities. By constructing and analyzing the game model between $\mathrm{C} 2 \mathrm{C}$ e-commerce operators and tax authorities, a mixed decision-making Nash equilibrium between the two parties is proposed, and feasible solutions are proposed based on the analysis results.

From the necessity of $\mathrm{C} 2 \mathrm{C}$ e-commerce tax collection and management, it is concluded that full implementation of $\mathrm{C} 2 \mathrm{C}$ e-commerce tax collection and management is an inevitable trend of economic market development. Due to the particularity of $\mathrm{C} 2 \mathrm{C}$ e-commerce transactions and the rapid development of modern information technology, the construction of my country's C2C e-commerce tax collection and management system is relatively lagging. As a large scale and a mature mode of transaction, $\mathrm{C} 2 \mathrm{C}$ e-commerce meets the requirements of taxation. However, $\mathrm{C} 2 \mathrm{C}$ e-commerce has long been in the "tax gap" area, which undoubtedly undermines fair competition with traditional retailers. The lack of tax fairness does not contribute to the optimization and development of China's tax system. The tremendous impact of $\mathrm{C} 2 \mathrm{C}$ e-commerce on the customary way of operation has virtually expanded the impact of $\mathrm{C} 2 \mathrm{C}$ tax loopholes on maintaining the neutral tax policy, which does not conducive to the further optimization and upgrading of China's market capital structure. It is not conducive to the sustainable development of e-commerce in China. It is necessary to demonstrate the necessity of $\mathrm{C} 2 \mathrm{C}$ e-commerce tax collection and management from three aspects: avoiding tax losses, maintaining fair market competition, and maintaining the principle of tax neutrality. It can 
comprehensively reflect the loopholes in the existing tax collection and management system and the optimization of China's tax system from a theoretical and practical perspective.

Through the mixed decision-making game analysis of $\mathrm{C} 2 \mathrm{C}$ e-commerce operators and tax authorities, it is concluded that when the taxable income remains unchanged, reducing the e-commerce income tax rate or increasing the tax evasion penalty will increase the probability of voluntary tax payment by business operators. The tax evasion amount of the operator will be inversely proportional to the inspection probability of the tax authority and increasing the penalty for tax evasion and evasion can reduce the inspection cost. Under the assumption of "economic man", the main business of C2C e-commerce will be in a certain degree of concealment.

The tax authorities will conduct tax rates and audits on the incentive and monitoring measures implemented by $\mathrm{C} 2 \mathrm{C}$ e-commerce operators. By encouraging and advocating $\mathrm{C} 2 \mathrm{C}$ e-commerce as a mature mode of operation in contemporary society and maintaining a fair and stable market competition in traditional retail mode, the violation cost of $\mathrm{C} 2 \mathrm{C}$ e-commerce operators in market competition can be raised through monitoring. While maintaining fair market competition, we have also complied with the principle of tax neutrality. In summary, the reasonable taxation behavior of tax authorities will help reduce the tax evasion of $\mathrm{C} 2 \mathrm{C}$ e-commerce operators, maintain a good market competition environment, promote the sustainable development of e-commerce, and standardize the implementation of the e-commerce tax system.

From the two aspects of qualitative analysis and quantitative analysis, the paper demonstrates the necessity of comprehensively regulating the implementation of $\mathrm{C} 2 \mathrm{C}$ e-commerce taxation in China. Combining the results of the analysis, from the perspectives of tax incentives, punishment of tax evasion and taxation innovation, the countermeasures to promote $\mathrm{C} 2 \mathrm{C}$ e-commerce taxation are proposed. This is not only a theoretical innovation in the field of e-commerce taxation, but also a useful exploration of my country's $\mathrm{C} 2 \mathrm{C}$ e-commerce taxation practice. The follow-up study of this article can try to further analyze different types of e-commerce business entities, such as B2C and $\mathrm{B} 2 \mathrm{~B}$ e-commerce operators. In addition, $\mathrm{C} 2 \mathrm{C}$ e-commerce will obtain a large amount of data during its operation. Using modern research theories and methods to conduct empirical research on corporate entities or taxation based on $\mathrm{C} 2 \mathrm{C}$ data will help improve research results in this field. 


\section{REFERENCES}

Al-Momani, A. M., Mahmoud, M. A., \& Ahmad, M. S. (2018). Factors That Influence the Acceptance of Internet of Things Services by Customers of Telecommunication Companies in Jordan. Journal of Organizational and End User Computing, 30(4), 51-63.

Biswas, S., Devi, D., \& Chakraborty, M. (2018). A Hybrid Case Based Reasoning Model for Classification in Internet of Things (Iot) Environment. Journal of Organizational and End User Computing, 30(4), $104-122$. doi:10.4018/JOEUC.2018100107

Fabisiak, L. (2018). Web Service Usability Analysis Based on User Preferences. Journal of Organizational and End User Computing, 30(4), 1-13.

Fan, Y. J. (2004). Analysis of logistics bottlenecks in the development of e-commerce. Business Times., 22(17), 51-52.

Gentile, B., Twenge, J., Freeman, E. C., \& Campbell, W. K. (2012). The effect of social networking websites on positive self-views: An experimental investigation. Computers in Human Behavior, 28(5), $1929-1933$. doi:10.1016/j.chb.2012.05.012

Grubljesic, T., Coelho, P. S., \& Jaklic, J. (2019). The Shift to Socio-Organizational Drivers of Business Intelligence and Analytics Acceptance. Journal of Organizational and End User Computing, 31(2), 37-64.

Ilies, R., Fulmer, I. S., Spitzmuller, M., \& Johnson, M. D. (2009). Personality and citizenship behavior: The mediating role of job satisfaction. The Journal of Applied Psychology, 94(4), 945-959. doi:10.1037/a0013329 PMID:19594236

Ilies, R., Scott, B. A., \& Judge, T. A. (2006). The interactive effects of personal traits and experienced states on intraindividual patterns of citizenship behavior. Academy of Management Journal, 49(3), 561-575. doi:10.5465/ amj.2006.21794672

Ivanaj, S., Nganmini, G. B., \& Antoine, A. (2019). Measuring E-Learners' Perceptions of Service Quality. Journal of Organizational and End User Computing, 31(2), 83-104. doi:10.4018/JOEUC.2019040105

Jiang, Z. Z., \& Wang, D. W. (2005). Model and algorithm of location optimization of distribution center in B2C e-commerce. Control and Decision., 20(10), 1125-1128.

Judge, T. A., Heller, D., \& Mount, M. K. (2002). Five-factor model of personality and job satisfaction: A metaanalysis. The Journal of Applied Psychology, 87(3), 530-541. doi:10.1037/0021-9010.87.3.530 PMID: 12090610

Judge, T. A., Locke, E. A., Durham, C. C., \& Kluger, N. C. (1998). Dispositional effects on job and life satisfaction:The role of core evaluations. The Journal of Applied Psychology, 83(1), 17-34. doi:10.1037/00219010.83.1.17 PMID:9494439

Judge, T. A., Rodell, J. B., Klinger, R. L., Simon, L. S., \& Crawford, E. R. (2013). Hierarchical representations of the Five-Factor model of personality in predicting job performance: Integrating three organizing frameworks with two theoretical perspectives. The Journal of Applied Psychology, 98(6), 530-541. doi:10.1037/a0033901 PMID:24016206

Khatwani, G., \& Srivastava, P. R. (2018). Impact of Information Technology on Information Search Channel Selection for Consumers. Journal of Organizational and End User Computing, 30(3), 63-80.

Lee, H. L., \& Whang, S. (2001). Winning the last mile of e-commerce. MIT Sloan Management Review, 42(4), 54-62.

Li, Z. F. (2011). Discussion on the relationship between enterprise logistics management and e-commerce. Modern Business., 12(18), 10-11.

Lu, Y. B., Zhao, L., \& Wang, B. (2010). From virtual community members to C2C e-commerce buyers: Trust in virtual communities and its effect on consumers' purchase intention. Electronic Commerce Research and Applications, 9(4), 346-360. doi:10.1016/j.elerap.2009.07.003

Peng, J. P., Quan, J., \& Peng, L. (2019). It Application Maturity, Management Institutional Capability and Process Management Capability. Journal of Organizational and End User Computing, 31(1), 61-85. 
Pham, L. M. T., Tran, L. T. T., Thipwong, P., \& Huang, W. T. (2019). Dynamic Capability and Organizational Performance: Is Social Networking Site a Missing Link? Journal of Organizational and End User Computing, 31(2), 1-21.

Ramakrishnan, R. (2010). The moderating roles of risk and efficiency on relationship between logistics performance and customer loyalty in e-commerce. Transportation Research. Part E, 950-962. .10.1016/j. tre.2010.02.002

Shahri, A., Hosseini, M., Phalp, K., Taylor, J., \& Ali, R. (2019). How to Engineer Gamification: The Consensus, the Best Practice and the Grey Areas. Journal of Organizational and End User Computing, 31(1), 39-60.

Tan, Q. M., \& Wang, Z. L. (2004). A study on the role of urban logistics in pulling economy 1 . Take Nanjing, Jiangsu as an example. Industrial Technology and Economy., 23(1), 89-91.

Wei, C. L., \& Ho, C. T. (2019). Exploring Signaling Roles of Service Providers' Reputation and Competence in Influencing Perceptions of Service Quality and Outsourcing Intentions. Journal of Organizational and End User Computing, 31(1), 86-109. doi:10.4018/JOEUC.2019010105

Zhang, S. X., \& Huo, J. Z. (2007). Research on the planning of multi-tier city logistics distribution system in the Yangtze River Delta. Science and Technology Progress and Countermeasures., 24(6), 50-53.

Zhang, L. X. Z., Mouritsen, M., \& Miller, J. R. (2019). Role of Perceived Value in Acceptance of "Bring Your Own Device" Policy. Journal of Organizational and End User Computing, 31(2), 65-82.

Zhao, G. J., \& Li, H. (2003). The impact of e-commerce on logistics development. Journal of Beijing University of Posts and Telecommunications, 4(4), 26-30. 